\begin{tabular}{rr} 
çağdaş & Yaratıcı Drama Dergisi 2017, 12(2), 127-136 \\
drama & www.yader.org \\
\hline
\end{tabular}

\title{
Yaşayan ve Yaşatan Müze
}

\section{Serap Buyurgan ${ }^{1}$}

\begin{tabular}{|c|c|}
\hline Makale Bilgisi & Öz \\
\hline DOI: $10.21612 /$ yader.2017.018 & $\begin{array}{l}\text { Müze, yaşama dair her alanın objelerini, anılarını, tüm yaşanmışlıklarını içinde } \\
\text { barındıran mekândır; yaşam boyu ögrenmenin gerçekleştiği en önemli yaygın eğitim }\end{array}$ \\
\hline Makale Geçmişi & $\begin{array}{l}\text { kurumlarındandır. Müzeler, sergi salonları, konferans salonları, kütüphaneleri, alıș } \\
\text { veris alanlart, bahceleri ve kafetervaları ile yasamın tam icerisinde yer alan, vasavan }\end{array}$ \\
\hline Geliş tarihi & ve içerisinde barındırdığ d dünyayı en etkili şekilde izleyicisine yaşatan mekânlar \\
\hline 15.08 .2017 & $\begin{array}{l}\text { olarak karşımıza çı̈kmaktadır. On dokuzuncu yüzyıldan sonra müzenin eğitim } \\
\text { boyutu en önemli görevlerinden biri olmuştur; müzeler eğitim birimleri oluşturarak } \\
\text { okullara, ögrenci ve ögretmenlere, ailelere, her tür engel grubuna, resmi kurum } \\
\text { ve kuruluşlara yönelik eğitim hizmetleri vermeye başlamiştır. Çalışmanın amacr, } \\
\text { araştırmacı tarafindan Anadolu Medeniyetleri Müzesi'ne yönelik programlanan iki }\end{array}$ \\
\hline Anahtar Sözcükler & ayrı ögrenci grubu ile gerçekleştirilen müze ziyaretlerinin, öğrencilere yaşattıklarını, \\
\hline Yaşayan müze & çalışmada, Gazi Universitesi, Gazi Eğitim Fakültesi, Görme Engelliler Eğitimi \\
\hline Müzede öğrenme & $\begin{array}{l}\text { Anabilim Dalı'nda } 2007-2008 \text { eğitim ögretim yllında 3. sinıfa devam eden, görme } \\
\text { vetersizliöi olan bes ögrenci ile gerceklestirilen "Görme Yetersizliöi Olan Üniversite }\end{array}$ \\
\hline Kalıcı ögrenme & 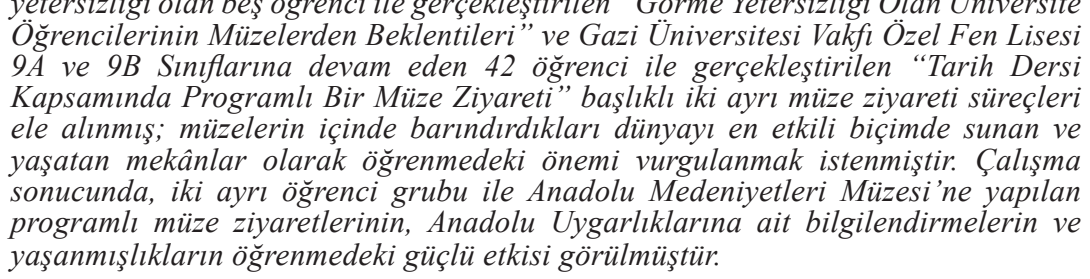 \\
\hline
\end{tabular}

\section{Live Museums Keeping Us Alive}

$\frac{\text { Article Info }}{\text { DOI: } 10.21612 / \text { yader.2017.018 }}$

\section{Article History}

Received $\quad 31.03 .2017$

Accepted $\quad 15.08 .2017$

\section{Keywords}

Live museums

Learning in museums

Permanent learning

\begin{abstract}
Museums are places containing all objects of life, memories, all experiences of life; which are the most important formal education institutions that life-long learning take place. Museums are such places keeping spectators alive in a very effective way with their exhibition halls, conference halls, libraries, shopping areas, gardens and cafeterias. After 19th century, education of museums became one of this field's most important tasks; and began to provide training to educators, schools, students and teachers, families, all types of disability groups, government agencies and institutions. This descriptive paper emphasizes the educational effects of two differently programmed visits to Anatolian Civilizations Museum in terms of experiences and achievements of students. The aim of the research is to learn the existing museum information of five 3rd grade university students with visual impairment in Gazi University, Faculty of Education, Education of Visual Impaired Students Department; to determine the achievements of museum learning and to make more efficient museum visits in Turkey. For this purpose, a programmed museum visit to Anatolian Civilizations Museum for university students with visual inadequacy was organized. At the same time, the achievements of 42 students of $9 \mathrm{~A}$ and $9 B$ classes of Gazi University, Private Science High School were revealed with the programmed visit to Anatolian Civilizations Museum within the scope of History Course. These visits to museums related to organized activities are efficient; the students are informed about Anatolian Civilizations' way of life, beliefs and arts; and learning in Anatolian Civilizations Museum with real objects and animations is more exciting and interesting than class environment. The powerful influence of learning in museums in terms of information and experience about Anatolian civilizations has been observed.
\end{abstract}

Prof. Dr. Serap BUYURGAN, Başkent Üniversitesi, Güzel Sanatlar Tasarım ve Mimarlık Fakültesi, Görsel Sanatlar ve Tasarım Bölümü, E-posta: sbuyurgan@baskent.edu.tr.

** Çalışmada yer alan birinci araştırma, Kuram ve Uygulamada Eğitim Bilimleri/ Educational Sciences: Theory \& Practice, Yaz (2009) 9(3) sayısında basılan “The Expectations of the Visually Impaired University Students from Museums", başlıklı yayından alınmıştır.

*** Çalışmada yer alan ikinci araştırma, 12-14 Mayıs 2007 tarihlerinde Bakü’de gerçekleştirilen, Hacettepe Üniversitesi Eğitim Fakültesi ve Azerbaycan Devlet Pedagoji Üniversitesi “Uluslararası Öğretmen Yetiştirme Politikaları ve Sorunları Sempozyumu”nda sunulan “Tarih Dersi Kapsamında Programlı Bir Müze Ziyareti” başlıklı bildiriden alınmıştır. 


\section{Giriş}

Müze, “Toplumun ve gelişiminin hizmetinde olan, halka açık, insana ve yaşadığ çevresine tanıklık etmiş malzemelerin üzerinde araştırmalar yapan, toplayan, koruyan, bilgiyi paylaşan ve sonunda inceleme, eğitim ve zevk alma doğrultusunda sergileyen, kâr düşüncesinden bağımsız, sürekliliği olan bir kurumdur." (Madran, 1999, s.6). Yine müze, "Gözlem, mantık, yaratıc1lı, hayal gücü ve beğeni duygusunun oluşmasına ve gelişmesine katkıda bulunabilecek başlıca yaygın eğitim kurumlarıdır." (Atagök, 1999, s.137). Müzeler, içinde yaşattıkları dünyayı gerçek objelerle insanlara sunan, her alanın öğretisinin en heyecan verici şekilde gerçekleşebileceği, insanın yaşamının her anında gitmek istediği zaman gidebileceği, kapılarının tüm insanlara daima açık olduğu okullardır. "Sanatsal, bilimsel, geleneğe ait, tarihi, teknoloji ve doğaya ait alanlarda, geçmişin, bugünün ve geleceğin izlerini içinde barındıran, görerek, işiterek, uygulama yaparak, hatta yaşayarak öğrenmenin gerçekleştiği, halka açık heyecan verici öğrenme mekânlarıdır” (Buyurgan ve Buyurgan, 2012, s.68).

Müzeler, birçok farklı alana ait objeyi, duyguyu, yaşamı içinde barındırırlar. Bizlere içinde barındırdıkları dünyayı en etkili sergileme yöntemleriyle, bilmiyorsak öğretmeye, unutmuşsak hatırlatmaya çalışırlar. Müzelerin öğrenmedeki bu pozitif etkisi 19. yüzyılın başlarında müzelerin en önemli görevlerinden biri olarak karşımıza çıkar; özellikle gelişmiş ülkelerde müzeler birer eğitim mekânı olarak kullanılır; müzeler, okullara, öğretmenlere, öğrencilere, ailelere, engellilere, kurum ve kuruluşlara, toplumun her kesimine yönelik eğitim etkinlikleri sunar; uygun fiziki donanım oluştururlar. Ülkemiz müzelerinde de eğitim birimlerinin oluşturulması, müzelerin okullara, öğretmen ve öğrencilere, topluma eğitim hizmetleri sunması her geçen gün artarak devam etmektedir. Ülkemizde müze gezme bilincinin daha fazla gelişmeye başladığı, müzede eğitim adına yapıcı adımların atıldığı, olumlu gelişmelerin her geçen gün fazlalaştı̆̆ 1 görülmektedir.

Sanatın, bilimin, tarihin, doğanın ve kültürün öğretilmesinde, korunmasında, nesilden nesile aktarılmasında müzelerin rolü büyüktür. Bir sanat müzesi sanata ait bilgilendirmenin, sorgulamanın, yeni düşünce şemaları geliştirmenin en önemli mekânlarından biridir. Arkeoloji müzesinde yer alan geçmiş uygarlıklara ait gerçek objeler, insanoğlunun doğa karşısında var olma savaşını ve gelişimini canlı canlı gözler önüne serer. Tabiat tarihi müzesi, tabiatın, hayvan 1rklarının varoluşunu; etnografya müzeleri geleneğin izlerini, dilin gelişimini, el sanatlarının toplumların oluşumundaki önemini en iyi anlatan mekânlardır. Kurtuluş Savaşımız ve Türkiye Cumhuriyeti'nin varoluş bilinci, en etkili biçimde o günlere ait objelerin yer aldığı müzelerde ve gerçek mekânlarda yaşanabilir ve yaşatılabilir. Anıtkabir'deki Kurtuluş Savaşı ve Atatürk Müzesi'nin ikinci bölümünde oluşturulan Çanakkale Muharebeleri, Sakarya Meydan Muharebesi ve Büyük Taarruz ve Başkomutan Meydan Muharebeleri'ne ait panoramalar gibi etkileyici görsel ve işitsel sunuşlar bize Cumhuriyetimizin değerinin, topraklarımızın her karışının atalarımızın kanı ile nasıl sulandığının, Atatürk'ün ve Türk Milleti'nin kadın, erkek, çocuk, omuz omuza, özgür ve bağımsız Türkiye Cumhuriyeti için nasıl mücadele verdiklerinin en güzel tanıklarıdır. Bu bilinç ve ruh sadece kitaplardan öğrendiğimiz bilgilerle kazanılamaz. Görsel ve işitsel objelerle hele de gerçek mekânlarda ve gerçek objelerle sunulan öğrenme dünyası daha etkili, heyecan verici ve kalıcı olur (Buyurgan, 2006, s.23).

Ankara'da ilk müze, Kültür Müdürü Mübarek Galip Bey tarafından 1921 y1lında kalenin Akkale olarak isimlendirilen burcunda kurulur. Atatürk'ün telkinleriyle merkezde bir "Eti Müzesi" kurma fikrinden hareket edilerek diğer bölgelerdeki Hitit eserleri de Ankara'ya gönderilmeye başlanınca geniş mekânlara sahip bir müze binası gerekli görülür. Anadolu Medeniyetleri Müzesi, At 
Pazarı olarak isimlendirilen semtte, Ankara Kalesi’nin dış duvarının güney doğu kıyısında, yeni işlev verilerek düzenlenmiş iki Osmanlı yapısı olan Mahmut Paşa Bedesteni ve Kurşunlu Han'da yer alır. 1938 yılından 1968'e kadar devam eden bir restorasyon çalışması başlatılır. 1997 yılında Avrupa'da Yılın Müzesi seçilen, bugün kendine özgü koleksiyonları ile dünyanın sayılı müzeleri arasında yer alan Anadolu Medeniyetleri Müzesi'nde, Anadolu arkeolojisi, Paleolitik Çağdan başlayarak günümüze kadar Osmanlı devrinin bu tarihi mekânlarında kronolojik bir sırayla sergilenmektedir (www.anadolumedeniyetlerimuzesi.gov.tr).

\section{Yöntem}

Çalışma, betimsel özellikler taşımaktadır. Çalışmada, araştırmacı tarafından Anadolu Medeniyetleri Müzesi'ne yönelik programlanmış, iki farklı öğrenci grubu ile gerçekleştirilen “Görme Yetersizliği Olan Üniversite Öğrencilerinin Müzelerden Beklentileri” ve "Tarih Dersi Kapsamında Programlı Bir Müze Ziyareti” başlıklı iki ayrı müze ziyareti süreçlerinde öğrencilere öğretilen bilgiler, kazandırılan ve yaşatılan değerler ortaya koyulmaya çalışılmış; müzelerin yaşayan ve içinde barındırdıkları dünyayı yaşatan mekânlar olarak öğrenmedeki önemi vurgulanmak istenmiştir. Çalışma kapsamında incelenen müze ziyaretlerindeki öğrenci grupları Gazi Üniversitesi, Gazi Eğitim Fakültesi, Görme Engelliler Eğitimi Anabilim Dalı'nda 2007-2008 eğitim öğretim yılında 3. sınıfa devam eden, görme yetersizliği olan beş öğrenci ve Gazi Üniversitesi Vakfi Özel Fen Lisesi 9A ve 9B sinıflarına devam eden 42 öğrencidir.

\section{Görme Yetersizliği Olan Üniversite Öğrencilerinin Müzelerden Beklentileri}

Müzelerin öğrenmedeki rolü ve etkisi görüldükçe müzeler eğitim birimleri oluşturarak her tür izleyiciye göre (okullara, ailelere, resmi kurumlara, vatandaşlara, engellilere) programlar ve fiziki şartlar oluşturmaya başlar. Görme yetersizliği olan bireylere yönelik eğitim hizmetleri de gündeme gelir. Zihinsel, fiziksel, davranışsal ya da duyu organlarının zedelenmeye bağlı olarak tüm ya da kısmen işlevlerinde gözlenen kayıpların ortaya çıkardığı duruma yetersizlik denir. Birey yetersizliğine bağlı olarak çoğu insanın duyduğu gibi duymayabilir, gördüğü gibi görmeyebilir, öğrendiği gibi öğrenmeyebilir (Ataman, 1997).

Eğitsel açıdan kör, ağır derecede görme kaybı olan, öğrenmesi dokunarak, işiterek, konuşan kitaplardan dinleyerek gerçekleşebilen bireylerdir. Az gören ise, büyüteçle normal puntolu ve büyük puntolu yazılı materyali okuyabilecek, geometrik şekilleri ve renkleri ayırt edebilecek kadar görme yetersizliğinden etkilenen kişilerdir (Ataman, 2006). Görme yetersizliği olan bireylerin de günlük yaşam becerilerini kazanması ve hayatlarını sürdürebilmesi için öğrenmesi, eğitim görmesi gereklidir. Görme yetersizliği olan bireylerin öğrenmesinde dokunma, işitme, tat alma, koklama duyuları, özel öğrenme yöntemleri ve farklı mekânlar önemlidir. Müzeler de onlar için her alana ait objeleri içinde barındıran önemli eğitim mekânlarıdır. Ancak görme yetersizliği olan bireylerin müzelerden verimli faydalanabilmeleri için onlara yönelik programlar hazırlanmalı ve fiziki şartlar oluşturulmalıdır.

\section{Görme Engellilere Yönelik Müzede Eğitim}

1970’lerde müzelerde görme engellilere yönelik hizmetler artar. 1975'de Leicester'de Müze Eğitim Servisi Grubu ve Leicester Üniversitesi Müze Çalışmaları ve Yetişkin Eğitimi Bölümü’nün ortak çalışmaları ile bir konferans düzenlenir. Burada, farklı formda engeller, zihinsel gerilik, fiziksel özür ve görme bozukluğunu kapsayarak belirlenir ve tartış1ır. 1976 yılında Tate Galerisi'nde 
“Körler İçin Heykel” adı verilen bir sergi gerçekleşir. 1986’da Müze ve Galeriler Engelliler Derneği (MAGDA) engellilere yönelik çalışmalar için kurulur, eğitim ve tartışma seminerleri düzenlenir. 1989'ların sonunda İngiltere'de "sanat ve dokunma sahnesi”" çok ses getirir. Britanya'daki müze ve galerilerde 18 aylık dönem içinde bir düzinenin üzerinde geçici dokunma sergisi düzenlenir. 1993’te açılan Omero Müzesi'nin (Italy) amacı halkın ve görme engellilerin estetik ve kültürel değerlerini geliştirmektir. Müze görme engellilere, üç boyutlu modellerle, sözel tanımlamalarla, büyük baskı ve Braille duvar bilgilendirmeleri ve kataloglarla hizmetler sunar. Türkiye'deki müzelerden bazılarında da görme yetersizliği olan bireylere yönelik eğitim hizmetleri sunulmaktadır. Anadolu Medeniyetleri Müzesi’nde (Ankara) 2002 yılından itibaren görme engelli öğrencilere yönelik eğitim programları vardır. 2004 yılında Rahmi M. Koç Müzesi’nde (İstanbul) Altı Nokta Körler Vakfı ile birlikte “Görme Engelliler Eğitim Projesi” başlatılır. İstanbul Modern Sanat Müzesi de özel ihtiyaçları olan çocuklara özel programlarla sıradan bir ziyaretçi olmanın ötesine geçerek müze koleksiyonu ile etkin bir biçimde karşılaşma yolları sunar. Bazı müzelerimizdeki bu hizmetlere rağmen ülkemiz müzelerinde görme yetersizliği olan bireylere sunulan hizmetler henüz istenilen seviyede değildir. Birçok müzemizde onların ihtiyaçlarına yönelik fiziki şartlar, özel öğrenme yöntemleri ya hiç yoktur ya da yok denecek kadar azdır (Buyurgan, 2009, s.1170-1173).

\section{Çalışma Grubu}

Araştırma küçük bir grupla yapılan örnek olay çalışmasıdır. Araştırmanın örneklemini, Gazi Üniversitesi, Gazi Eğitim Fakültesi, Görme Engelliler Eğitimi Anabilim Dalı'nda 2007-2008 eğitim öğretim yılında 3. Sınıfa devam eden, "Görme Engellilerde Resim ve Modelaj Öğretimi" dersini alan beş görme yetersizliği olan öğrenci oluşturmaktadır. Öğrencilerin üçü total kör, ikisi de az görendir. Total kör öğrencilerin iki tanesi akraba evliliği yapan ailelerden gelmektedir; doğuştan kördürler, \%100 görmemektedirler. Diğeri de iki yaşında tamamen görme gücünü kaybetmiştir. O da \%100 görmemektedir. Az gören öğrencilerin de bir tanesi akraba evliliği yapan aileden gelmektedir. Gündüz \%15, gece ise \% 5 görmektedir (gece körlüğ̈̈). Diğerinin ise sağ gözü \%100 görmemekte; sol gözünde ise 1/10 görme vardır (nistağmus) (Buyurgan, 2009, s.1167-1175).

Araştırma tarama modelinde nitel bir çalışmadır. Küçük bir grupla yapılan örnek olay çalışmasıdır. Nitel veriler, görüşme formları, gözlem ve müze ziyareti sonrasında öğrencilerin duygularını anlattıkları kompozisyonlardan elde edilmiştir. Araştırma verileri içerik analizi ile kodlanmış, alt temalar ve temalar oluşturulmuştur. Görüşme formları araştırmaya katılan kör öğrencilere araştırmacı tarafindan uygulanmıştır. Ön görüşme formu müze ziyaretinden bir hafta önce, son görüşme formu da müze ziyaretinden sonra araştırmacının odasında uygulanmıştır. Tüm öğrenciler önceden yer ve saat konusunda bilgilendirilmiştir. Kör öğrenciler odaya teker teker alınarak sorular okunmuş, yönlendirmesiz bir görüşme tekniği ile cevaplar görüşme formlarına kaydedilmiştir. Az gören öğrenciler görüşme formlarını aynı günlerde, atölyede, pencerenin yanında 1şıklı bir ortamda kendileri doldurmuştur. Görüşme formları az gören öğrencilerin rahat okuyabilmeleri için 16 punto, büyük harf ve koyu yazılmıştır. Sorular arasında bırakılan cevap boşlukları da geniş tutulmuştur. Gözlem, müzeye gidilen günün sabahında toplanılan üniversite bahçesinde, müze ziyaret sürecinde ve müze ziyaretinden sonra gidilen üniversitede atölyede yapılmıştır. Gözlem notları araştırmacı tarafından kayıt altına alınmıştır. Tüm müze ziyareti, öncesi ve sonrasıyla fotoğraflarla da belgelenmiştir. Fotoğraflar müze ziyaretine eşlik eden bir yüksek lisans öğrencisi tarafından çekilmiştir. Öğrenciler, müze ziyareti ile ilgili yazdıkları kompozisyonları müze 
ziyaretinden bir hafta sonraki derste teslim etmişlerdir. Kör öğrenciler de duygularını klavyesi Braille alfabesi olan bilgisayarlarda kendileri yazmışlardır (Buyurgan, 2009, s.1173-1174).

\section{Bulgular ve Yorumlar}

Görüşme formlarındaki verilerden elde edilen kodlardan alt temalar ve üç ana tema elde edilmiştir.

\section{Görme Yetersizliği Olan Üniversite Öğrencilerinin Müze ile İlgili Var Olan Bilgileri}

Müze ziyareti öncesinde yapılan ön görüşme formu sonuçları öğrencilerin müze ile ilgili yetersiz bilgiye sahip olduklarını; \%80'inin eserlerin müzeye nasıl toplandığ 1 ile ilgili hiçbir fikre sahip olmadıklarını göstermiştir. Bir öğrencinin "Eserler camın arkasında diye duydum" (Ö.1) yorumu bu sonucu desteklemektedir. 21 Mayıs 2008 tarihinde sabah 9.00'da üniversitenin bahçesinde buluşulur. Bütün öğrenciler heyecanlı ve meraklıdır. Bahçede topluca fotoğraf çektirilir. Bütün öğrenciler "çekiyorum” sesine doğru mutlulukla gülümser. Müzeye iki araba ile gidilir. Müze ziyareti boyunca beş görme engelli öğrenciye, araştırmacı, müze eğitimcisi ve iki yüksek lisans öğrencisi refakat eder. Önce müzenin bahçesindeki heykeller dokunarak incelenir. Öğrenciler insan heykellerinin bazılarının başlarının neden olmadığını sorar. Cevabını öğrenirler. Heykellerin elbiselerinin kıvrımlarını incelerler. Kör öğrenciler aslan heykelini kendileri tasvir eder. Ayağını bulur; yelelerini inceler; yelelerin ne olduğunu sorarlar. Aslanın duruşunu fark ederler. Bu oturuyor derler. Bir önce inceledikleri insan heykelinden sonra onun bir hayvan olduğunu kendileri fark ederler. Kör öğrencilerden biri aslan heykelinin gerçek aslan ile büyüklüğünün aynı olup olmadığını sorar. Müze bahçesinde az gören öğrenciler yeterli gün 1şığından dolayı kendileri hareket ederler. Ancak müze içerisinde refakat edilmesine ihtiyaç duyarlar (1şık yeterli gelmez, müze kalabalıktır). Müzeye girilince öğrenciler önce orta salona alınır. Burada oturma bölümüne oturulur. Araştırmac1 tarafından, Müze nedir? Müze çeşitleri nelerdir? Müzeye eserler nasıl toplanır? Soruları ile ilgili işitsel bilgilendirmeler yapılır. Müzelerle ilgili belirli bir bilgi birikimi kazandırılır. Müze eğitimcisi müze binaları ile ilgili bilgilendirme yapar. Öğrencilere o anda içinde bulundukları Mahmut Paşa Bedesteninin büyüklüğü, neden Kurşunlu Han ile yan yana olduğunu anlatır. Alışverişe gelen tüccarların kalabilmesi için hanın yanına yapıldığı söylenir. Öğrencilere bulundukları binanın büyüklüğü ile ilgili bilgi verilir. Müze eğitimcisi bedestenin (alışveriş merkezi) ne amaçla yapıldığını anlatır. Burada binanın yapıldığı tarihlerde yün, ipek, deri satıldığını söyler. Görme yetersizliği olan öğrencilerin ellerine yün ve deri verilir. Yünden, deriden neler yapılabileceği konuşulur. Ellerine yün eğirme aleti olan "kirmen" verilir. Aletin nasıl kullanıldığı öğretilir (Buyurgan, 200, s.1175-1179).

Müze, müze eğitimcisinin bilgilendirmeleri eşliğinde gezilir. Bazı eserlerin önünde oturulur. İşitsel bilgilendirmelerin yanında bazı eserlerin kopyaları ile dokunsal öğrenme de yaşanır. Görme engelli öğrenciler müzede bulunan kapları, balta uçlarını, törensel sembolleri insanların ihtiyaçlarını karşılamak için yaptıklarını öğrenirler. Güneş Kursunun karşısında otururlar. Karşılıklı soru ve cevaplarla Hattiler'deki ve geçmiş dönemlerdeki din anlayışı anlatılır. Güneş Kurslarının, bazı seramik kapların ve tabletlerin taklitleri ile anlatılanları elleri ile görselleştirirler. Öğrencilere elle yapılmış ve çarkta yapılmış seramik örnekleri dağıtılarak seramiğin zaman içerisindeki gelişimi anlatılır. Seramiklerin üzerlerindeki süslemelerin estetik kaygı ile yapıldıkları söylenir. Yine taklidine dokunarak ilk çalgı aletini tanırlar. Burada dokundukları taklit objelerin gerçekleri ile aynı büyüklükte olup olmadığını sorarlar. Asur Ticaret Kolonileri Dönemi eserlerinin bulunduğu vitrinlerin önünde 
de otururlar. Yazının Anadolu'ya M.Ö. 2000'li yıllarda Asur Ticaret Kolonileri Çağı'nda geldiğini, müzede sergilenen tabletlerde neler yazıldığını, çivi yazısının nasıl yazıldığını öğrenirler. Bir vitrinde bir katip tarafından çivi yazısının nasıl yazıldığ 1 ve pişirildiği canlandırılmıştır. Bu canlandırma araştırmacı tarafından tüm detayları ile görme yetersizliği olan öğrencilere anlatılır. Yine tanrılara içki sunmak için kullanılan "riton” lardan (törensel içki kabı) biri az gören bir öğrencinin dikkatini çeker. Uzun boyunlu, üzerinde hayvan heykelcikleri olan, baş kısmı dokularla süslü bu riton detaylı olarak tasvir edilir. İçkinin nereden akıtıldığ 1 anlatılır. Kral Midas'ın mezarından çıkarılan ölü hediyeleri anlatılır (sehpalar, kazanlar, kaplar). Amerikalılar tarafindan mezardan çıkarılan kazanlara yapılan DNA testi ile ölü yemeğinde neler yendiğinin (dana eti, kuzu eti, ballı bira) ortaya çıkarıldı̆̆ 1 söylenir. Frig ana tanrıçası Kibele'nin önünde Neolitik dönemden beri var olan ana tanrıça inancı anlatılır. Bolluk ve bereketi simgeleyen ana tanrıçalara farklı dönemlerde farklı isimler verildiği söylenir (Kibele, Kubaba gibi). Son olarak müze eğitim atölyesine gidilir. Görme yetersizliği olan öğrenciler burada sikke (metal para) ile ilgili bilgi edinirler. Dokunarak geçmiş dönemlerin sikkelerini tanırlar. Her öğrenci tek tek sikke basar. Hepsi son derece heyecanlıdır; çok eğlenirler. Bastıkları sikkeler günün anısına onlara verilir. Çok mutlu olurlar. Müze eğitim atölyesinin duvarlarındaki rölyefleri dokunarak incelerler. Müze bahçesinden arabalarına giderken araştırmacıya kendilerini çok değerli hissettiklerini söylerler. Onların öğrenme yöntemlerine yönelik, ihtiyaçları dikkate alınarak organize edilen bu samimi müze ziyareti hepsini çok mutlu eder. Topluca üniversiteye dönülür. Atölyede biraz dinlendikten sonra son görüşme formu doldurulur. Görüşme formu kör öğrencilere araştırmac1 tarafından, ayrı bir odada tek tek uygulanır. Yorulmuşlardır ama yüzleri sürekli gülmektedir. Hepsi öğretmenlerini öperek atölyeden ayrılırlar (Buyurgan, 2009, s.1179-1180).

\section{Müzede Öğrenmenin Görme Yetersizliği Olan Üniversite Öğrencileri Üzerindeki Kazanımları}

Müzede görme engelli öğrenciler Anadolu Uygarlıklarının yaşam şekillerini, inançlarını ve sanatlarını dokunarak ve işitsel bilgilenmelerle öğrenmişlerdir. Müzede öğrenme sınıf ortamından daha heyecan verici ve ilgili olmuştur. Araştırma bulguları, müze ziyareti öncesinde, görme yetersizliği olan üniversite öğrencilerinin müze ile ilgili belirli bir bilgi birikimine sahip olmadıklarını göstermiştir. Araştırma kapsamında, öğrenme yöntemlerine yönelik programlanan, işitsel bilgilendirmeler, dokunarak, sözel betimlemeler, soru-cevaplarla ve uygulama yaparak gerçekleştirilen müze ziyaretinin veriminin yüksek olduğu görülmüştür. Öğrenciler müze ziyareti boyunca gülümsemiş, öğrendikleri karşısında şaşırmış, sürekli sorular sormuştur. Kendilerini önemli hissetmişlerdir (Buyurgan, 2009, s. 1180-1182).

\section{Görme Yetersizliği Olan Üniversite Öğrencilerinin Türkiye Müzelerinden Beklentileri}

a. Görme Yetersizliği Olan Üniversite Öğrencilerinin Türkiye Müzelerinden Fiziki Ortam ve Öğrenme Yöntemleri Olarak Beklentileri

b. Görme Yetersizliği Olan Üniversite Öğrencilerinin Anadolu Medeniyetleri Müzesi'nden Fiziki Ortam ve Öğrenme Yöntemleri Olarak Beklentileri

Görme yetersizliği olan üniversite öğrencilerinin genel anlamda ülkemiz müzelerinden ve ziyaret edilen Anadolu Medeniyetleri Müzesi'nden beklentileri benzerlik göstermiştir. Araştırma verilerine göre, kör öğrenciler müzelerimizden, kendilerine bilgilendirme yapacak görevliler, eserlerin kopyaları, kabartma resimler ve Braille alfabesi ile açıklamalar olmasını, az gören öğrenciler de ortamın aydınlık ve ferah düzenlenmesini, sergilemelerde zıt renklerin kullanılmasını, yazıların 
büyük punto yazılmasını istemişlerdir. Araştırma sonucunda, görme yetersizliği olan üniversite öğrencilerine yönelik organize edilmiş müze ziyaretinin veriminin yüksek olduğu, ancak ülkemiz müzelerinde görmeye yetersizliği olan bireylere yönelik eğitim hizmetlerinin henüz yeterli seviyede olmadığ1 görülmüştür (Buyurgan, 2009, s.1182-1187).

\section{Tarih Dersi Kapsamında Programlı Bir Müze Ziyareti}

$\mathrm{Bu}$ çalışmada ele alınan ikinci araştırmada, Tarih dersi kapsamında, Anadolu Medeniyetleri Müzesi’ne götürülen, Gazi Üniversitesi Vakfı Özel Fen Lisesi 9A ve 9B Sınıflarına devam eden 42 öğrenci ile gerçekleştirilen programlı müze ziyareti süreci ve öğrencilerin kazanımları ortaya koyulmuştur. Öğrencilerin, Anadolu Uygarlıkları ünitesini en istekli, bu dönemlere ait gerçek objeleri içinde barındıran Anadolu Medeniyetleri Müzesi'nde öğrenebilecekleri düşüncesinden hareketle müze ziyareti programlanmıştır. Ders öğretmeni ve müze ile bağlantı kurulmuş; öğrencilere etkin ve kalıcı öğrenmeyi sağlayacak, amaca uygun aktiviteleri kapsayan müze rehberi hazırlanmıştır. Lise 1. Sınıf Tarih Dersi II. Ünitesinin konuları Eski Çağlarda Türkiye ve Eski Çağlarda Türkiye'nin Çevresindeki Kültür Uygarlıklarıdır. Bu başlıkların açılımlarını, Taş Çağı (Paleolitik, Mezolitik, Neolitik), Kalkolitik Çağ, Tunç Çağı, Hititler, Frigyalılar, Lidyalılar, İyonyalılar, Urartular, Persler, İskender, Bizans ve Roma İmparatorlukları Dönemleri, Asurlular, Sümerler, Akadlar, Elam ve Babil Devletleri, bu uygarlıkların devlet yönetimi, din ve inanışları, sosyal ve ekonomik yaşamları, kullandıkları yazı, dil ve edebiyatları, bilim ve sanatları oluşturmaktadır. Bu ünitenin öğretiminde Anadolu Medeniyetleri Müzesi'nin gerçek objelerle en etkili ve sihirli dünyayı sunacağ1 düşünülmüş ve daha heyecan verici ve kalıcı öğrenmenin gerçekleşmesi amacı ile bu müze ziyareti programlanmıştır. Müze ziyareti üç aşamada gerçekleşmiştir. Ziyaret öncesi öğrencilere ön anket uygulanmıştır. Müzede, müze eğitim uzmanlarının bilgilendirmeleri eşliğinde müze gezilmiş; tabletler karsısında akıcı, esnek ve özgün düşünmeyi sağlayan çalışma yaprağı uygulanmıştır. Müze ziyareti bitiminde, akıcı düşünmeyi sağlayan çalışma yaprağı ve kazanımları ölçen son anket doldurulmuştur. Araştırmanın sonucunda, müze ziyareti sürecinde ilgili, heyecan verici ve kalıcı bir öğrenmenin gerçekleştiği görülmüştür (Buyurgan, 2007, s. 725-726).

Müze Ziyaretiöncesi: Öğrencilere, “Müzene demektir?”, "Hangitürmüzelervardır?”, "Daha önce hiç müzeye gittin mi? İsimlerini yazar mısın?”, "Daha önce Tarih dersinde öğrendiğin Anadolu Uygarlıkları ile ilgili müzede neler görmeyi umuyorsun?" ve "Müzeler ne ise yarar?" Sorularından oluşan ön anket uygulanmıştır. "Daha önce Tarih dersinde öğrendiğin Anadolu Uygarlıkları ile ilgili müzede neler görmeyi umuyorsun?" Sorusuna öğrencilerin \% 45'i eski paralar, belgeler, aletler, süs eşyaları, takılar, hayvan kürkleri, kral heykelleri, kitabeler, kral eşyaları, mühürler; \% 19'u uygarlıkların yaşadıkları sosyal, kültürel yaşantılarını anlatan şeyler; \% 16'sı resimler, yazılar, sanat eserleri; \% 14'ü öğrendiklerimizle ilgili gerçek kanıtlar görmeyi umuyoruz cevabını vermiştir. İşte bu öğrencilerin tanımlamasıyla "gerçek kanıtlar" insanı heyecanlandıran, görmeye-öğrenmeye daha istekli yapan, düşündüren belgelerdir. "Öğrenme sürecinde nesneler katalizör gibidir: Nesnelerin malzeme yönü, "gerçek olmaları", yazılı dünyaya gösterilen dikkatten niteliksel olarak farklı olan bir ilgiyi ya da dikkat yoğunlaşmasını uyandırma olanağına sahiptir. Doğal numuneleri ve maddi kültürü çalışmak duyuların kullanılması yoluyla beynin çalışmasını gerektirir" (Hooper-Greenhill, 1999, s. 127). "Müzeler ne ise yarar" sorusuna öğrencilerin \% 57'si tarihi öğrenmeye yarar; \% 21.4'ü insanların geçmişte ne tür sanatlarla uğraştığını öğretir, genel kültürümüzü geliştirir, uygarlık seviyesini gösterir; \% 7'si insanları bilinçlendirir cevabını vermiştir (Buyurgan, 2007, s.726-727). 
Müzede: Müze, müze eğitimcilerinin bilgilendirmeleri, tarih öğretmenleri, araştırmacı ve araştırmacının beş yüksek lisans öğrencisinin rehberliğinde ziyaret edilir. Soru-cevaplar ve çeşitli aktiviteleri kapsayan müze ziyareti, baştan sona ilgili, heyecanlı ve öğrenci katılımı ile geçer. Daha fazla bilgilendirme ve aktiviteler tarih dersi öğretmeninin vurgulamak istediği dönemler ve esreler karsısında yapılır. Öğrenciler, Neolitik Döneme ait duvar resimlerinin önünde neden daha çok boğa ve geyik resmi yapıldığını sorar. Bu hayvanların güç ve bereketi simgelediğini öğrenir. Dünyanın ilk şehir planını, ilk aynayı, ilk müzik aletini, ilk termosu vb. insanoğluna ait birçok ilkleri görürler, merakla sorularını sorarlar. Çivi yazısına çok ilgi gösterirler. Bu yazının çivi ile yazılmadığını, şekilleri çiviye benzediği için bu ismi aldığını öğrenince çok şaşırırlar. Öğrencilere Asur Ticaret Kolonileri Dönemi bölümünde, tabletlerin önünde bir etkinlik uygulanır. Önce yazının Anadolu'ya gelişi ve çivi yazısı ile ilgili bilgi verilir. Tabletler ve mektuplar ile ilgili açıklamalar yapılır. Bu belgelerin geçmiş ile ilgili bize ne tür bilgiler verdiğine değinilir. Çalışma kağıdında günümüz iletişimi ile ilgili sorular sorulur ve öğrencilere istedikleri bir kişiye mektup yazdırılır. Onların bu belgelerinin geleceğe günümüz ile ilgili bilgiler vereceği söylenir. Öğrencilerin \% 20'si "şu anda kullanılan iletişim araçlarının" telefon, \% 17'si internet, \% 12'si msn olduğunu ifade eder. "Sizce insanlar gelecekte nasıl haberleşecekler?" Sorusuna öğrencilerin \% 32'si ileri teknolojiyle, \% 26's1 1şınlama ile, \% 22'si telepati ile, \% 20'si de görüntülü iletişim ile cevabını verir. Verilen cevaplar öğrencilerin teknoloji ile ne denli iç içe olduklarının bir göstergesi gibidir. Aynı çalışma kağıdında öğrencilere istedikleri bir kişiye mektup yazdırılır. Elle mektup yazarken çoğunluğu zorlanır. Keşke bilgisayarımız olsaydı, onunla yazsaydık derler. Mektupların \% 28.4'ü arkadaşlarına, \% 21.4'ü sanatçılara, \% 16'sı aile bireylerine, \% 5'i Milli Eğitim Bakanı'na, \% 2.4’ü Başbakan'a yazılır. MEB'na yazılan mektuplarda OKS ve sınav sistemi eleştirilir, sıkıntıları anlatılır. Sonra mektuplar zarflara koyulur. Çoğunluğu zarf üzerine neler yazılacağını sorarlar. Zarflar yazılır ve araştırmacının uzattığı kağıt torbaya atılarak sembolik olarak postalanır. Asırlar öncesinin toprak üzerine yazılmış ve pişirilmiş mektupları ve konuları karsısında bugünün çocukları, bugünün yazısı ve iletişimini yaşarlar, geleceğin ipuçlarını verirler. Müze ziyaretinin sonunda öğrenciler orta salonda toplanır. Anadolu Medeniyetleri Müzesi’nde anlatılan dünyaya ait 16 kelimeden oluşan (fibula, kibele, idol, Karum, Hattuşaş vb.) bulmaca kağıdı dağıtılır; çok kısa bir sürede bütün öğrenciler eğlenceli bulmacayı çözer; yorgun ama mutlu okula dönülür (Buyurgan, 2007, s.727-728).

Müze ziyareti sonrası: Müze ziyaretinden sonra okulda öğrencilere müze ziyaretinin verimini ölçmek amacıyla son anket uygulanır. Son anket altı açık uçlu sorudan oluşur. "Bu müze ziyaretinde önemli olarak neleri ilk defa öğrendin?” Sorusuna öğrencilerin \% 18'i kadına önem verildiğini (ana tanrıça kavramını), \% 18'i ilk müzik aletini, \% 18'i ilk aynayı, \% 3’ü şu andaki Eti markasının ambleminin Hititlere değil Hattilere ait olduğunu, \% 3’ü kadınların o zaman bile süslü olduğunu öğrendiğini ifade eder. “Sence bu müze neden önemlidir?” Sorusuna öğrencilerin \% 71.4'ü bizim geçmişimiz olduğu için, \% 14'ü Anadolu' da yaşayan medeniyetlerin nasıl geliştiğini gösteren birçok eser bulundurduğu için, \% 2.3'ü geçmiş ile günümüz arasında köprü olduğu için önemlidir cevabını verir. "Başka hangi derslerinizi müzelerde yapabilirsiniz?” Sorusuna öğrencilerin \% 20.3’ü Fizik, \% 19.8'i Biyoloji, \% 14'ü Kimya, \% 5'i Resim derslerini cevabını verir ve Fen dersleri için Feza Gürsoy Bilim Merkezi’ni önerirler (Buyurgan, 2007, s.728-729). 


\section{Sonuç}

Müzeler, konferans salonları, kütüphaneleri, alış veriş alanları, kafeteryaları, eğitim atölyeleri ile sanat, gelenek, tarih sohbetlerinin yapılabildiği, konser dinlenip, sanata, bilime dair gelişmelerin yaşatıldığı farklı konferansların düzenlendiği, müzenin sunduğu dünyaya dair bir kitap ya da etkileyici bir obje satın alınabilecek müze dükkanlarının olduğu, yorulunca dinlenebileceğimiz oturma alanlarıyla, hem her alana ait bilgilenmenin yaşandığı hem de etkileyici ve kalıcı öğrenmenin sunulduğu mekânlardır (Buyurgan ve Buyurgan, 2012, s. 73). Günümüzde müzeler; eserleri toplamak, belgelemek, korumak, sergilemek ve bilgilendirmenin yanında, etkileyici sunumlarla olayları yaşatan, konferans salonları ile birçok bilimsel, sanatsal ve kültürel faaliyetlere ortam hazırlayan, kütüphaneleri, eğitim birimleri ve eğitim atölyeleri ile etkili ve kalıcı öğrenmeyi gerçekleştiren, kafeteryaları, bahçesi ve satış alanları ile ziyaretçilerine dinlenme ve müzeden anılarla ayrılma imkanı sağlayan yaşayan ve içinde barındırdığg dünyayı yaşatan mekânlar olarak karşımıza çıkmaktadır. Çalışma sonucunda, amaca yönelik hazırlanmış müze ziyaretleri ve Anadolu Medeniyetleri Müzesi’nin içinde barındırdığı dünyayı etkileyici sunuşları ile farklı öğrenme özellikleri olan öğrencilerin müzedeki ilgili ve istekli davranışları ile yaşayarak öğrenmenin etkisi ortaya konmuş; müzelerin yaşamın içerisindeki önemi ve gerekliliği gözler önüne serilmiştir.

\section{Kaynakça}

Atagök, T. (1999). Yeniden müzeciliği düşünmek. İstanbul: Yıldız Teknik Üniversitesi Basım Yayın Merkezi.

Ataman, A. (1997). Özel eğitim. L. Küçükahmet (Ed). Eğitim bilimine giriş içinde (s. 209-236). Ankara: Gazi Kitabevi.

Ataman, A. (2006). Görme yetersizliğinin çocuklar üzerindeki etkileri. U. Tüfekçioğlu (Ed.). İşitme, konuşma ve görme sorunu olan çocukların eğitimi içinde (s. 235-256). Eskişehir: Anadolu Üniversitesi Yayını.

Buyurgan, S. (2006). Müze eğitimi. Sanat sokă̆g. Ankara: Denge Matbaacılık. s. 22-25.

Buyurgan, Serap, (). Tarih dersi kapsamında programlı bir müze ziyareti Hacettepe Üniversitesi Eğitim Fakültesi ve Azerbaycan Devlet Pedagoji Üniversitesi Uluslararası Öğretmen Yetiştirme Politikaları ve Sorunlarl Sempozyumu. Bakü: 12 - 14 Mayıs 2007. www.egitim.hacettepe.edu.tr (Bildiri Kitabı) sf.725-729.

Buyurgan, S. (Summer 2009). The expectations of the visually impaired university students from museums, Kuram ve Uygulamada Eğitim Bilimleri/ Educational Sciences: Theory \& Practice, 9(3), s. 1167-1204. İstanbul: Eğitim Danışmanlığı ve Araştırmaları İletişim Hizmetleri Tic. Ltd. Şti. ISSN: 1303-0485

Buyurgan, S. ve Ufuk Buyurgan (2012). Sanat eğitimi ve öğretimi (Eğitimin her kademesine yönelik yöntem ve tekniklerle). Ankara: PegemA Yayınları.

Madran, B. (1999). Müze türleri. Yeniden müzeciliği düşünmek. Der: Tomur Atagök. İstanbul: Yıldız Teknik Üniversitesi Basım Yayın Merkezi.

(www.anadolumedeniyetlerimuzesi.gov.tr).

Hooper, E. Greenhill (1999). Müze ve galeri eğitimi. Çev. Meltem Örge Evren-Emine Gül Kapçı. Yayına Hazırlayan: Bekir Onur. Ankara Üniversitesi Çocuk Kültürü Araştırma ve Uygulama Merkezi yayınları No: 4 Ankara. 
